\title{
Die verhouding verkondiging en belydenis by Paulus
}

\author{
G M M Pelser \\ Departement Nuwe-Testamentiese Wetenskap (Afd A) \\ Universiteit van Pretoria
}

\begin{abstract}
The relationship between proclamation and confession in Paul

It is a well-known fact that in his letters Paul for different purposes made use of traditional materials, among others confessional formulae and hymns. In this study the question is asked as to how these materials were evaluated by Paul, that is, whether he regarded them as fixed dogmas to be handed down in their original form, and in the event of proclaiming the gospel, to be strictly adhered to as kerygmatic guidelines. The conclusion arrived at is that, although Paul definitely regarded these materials as existential expressions of faith of some importance and as forms of proclamation in their own right, he never saw them as unchangeable dogmas to be strictly adhered to as prescriptive for his understanding and proclamation of the gospel. He, on the contrary, made free use of them in such a manner that he modified them in different ways in order to bring them in line with his theology and to serve the purpose of his theological argument. In so doing, he clearly demonstrated that, in his view, the confessional formulae should be of service to the kerygma, and not the other way around.
\end{abstract}

\section{INLEIDING}

Die vraag wat met die titel hierbo aangedui word, is na my wete nog nie in die verlede presies so gevra nie, hoewel daar al verskeie studies onderneem is oor tradisiemateriaal by Paulus en hoe dit deur hom hanteer is. Wat verder opmerklik is, is dat daar reeds meer as drie dekades verloop het sedert die laaste betreklik uitvoerige studies oor tradisiemateriaal by Paulus en sy hantering daarvan gedoen is. In hierdie verband dink 'n mens veral aan die monografieë van Wegenast (1962) en Wengst (1967) en in 'n mindere mate dié van Deichgräber (1967). Die aandag wat sedertdien aan sodanige materiaal gegee is, vind 'n mẹns hoofsaaklik in kommentare en in monografiee oor Paulus se Christologie of teologie. Die oogmerk met hierdie studie is om te probeer 
vasstel wat Paulus se houding teenoor oorgelewerde tradisiestof of reeds geformuleerde belydenis-agtige materiaal was en hoe hy dit hanteer het wanneer hy daarvan in sy briewe gebruik gemaak het. Bloot die feit dat hy van hierdie materiaal op belangrike punte in sy verkondiging gebruik gemaak het, veroorloof ons die vraag na die gewig wat hy daaraan toegeken het en die funksie wat hy dit laat vervul het (so tereg Wegenast 1962:52). Die eintlike bedoeling met die vraag is om vas te stel of hy belydenisformules gesien het as kerklike erf- en leerstukke wat een of ander blywende geldigheid het en om hierdie rede onveranderd bewaar en oorgelewer moes word. Ook of hy hierdie belydenisse as bepalend vir sy denke oor en verkondiging van die Christusgebeure beskou het.

Soos hierna sal blyk, gaan die studie die vorm aanneem van altesaam ses stellings oor die onderwerp, wat elkeen op sy beurt motiverend toegelig sal word. Soos ook sal blyk, het ek dit nie nodig geag om uitvoerig te motiveer waar 'n stelling na my oordeel duidelik genoeg is en dus nie uitvoerige bewysvoering nodig het nie.

\section{DIE VOORKOMS VAN TRADISIEMATERIAAL BY PAULUS}

Paulus het by verskeie geleenthede en op strategiese punte in sy briewe gebruik gemaak van tradisiemateriaal waaronder belydenis-agtige formules en himnes of liedere.

Dat die vroegste Christene betreklik gou in die na-Pase periode hulle verstaan van die Christusgebeure deur middel van kortere of langere formulerings uitgedruk het, hoef nie beredeneer te word nie. Hiervan is daar immers meer as genoeg bewys in die dokumente van die Nuwe Testament (kyk Dunn 1977:359). Dit is daarom 'n feit en volkome te begrype dat Paulus se roeping tot apostel hom in aanraking gebring het met verskillende formules of formulerings waarin elemente van 'n reeds bestaande 'teologie', deur Schmithals (1994:70-86) genoem die 'Bekehrungstheologie' van Paulus, uitdrukking gevind het. Dat Paulus hom met hierdie teologie maar ook met ander vereenselwig het, blyk duidelik uit die neerslag wat dit in sy briewe gevind het, ' $n$ feit wat nie beredeneer hoef te word nie en waaroor daar in kritiese geleerdheid lank reeds eenstemmigheid bestaan (kyk Wegenast 1962:9). Al waaroor daar, soos verwag kan word, nie konsensus is nie, is oor wat wel met sekerheid as voor-Pauliniese materiaal beskou kan word en wár na die oorspronklike tuiste van hierdie formules gesoek moet word, naamlik of dit uit Joods-Christelike of Hellinisties-Christelike kring of uit albei afkomstig was. Soos bekend, is daar oor die voor-Pauliniese ontstaan van minstens twee van 
hierdie tradisiestukke (1 Kor 11:24-25; 15:3-5) nie twyfel nie, aangesien Paulus ten opsigte van albei self sê dat hy dit 'ontvang' en 'oorgelewer' het. Dit is wel opvallend dat hy ten opsigte van die tradisie oor die nagmaal nie in 1 Korintiërs 11:23 die te ver-

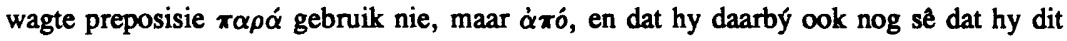
$\dot{\alpha} \pi \grave{o}$ Tôे kupíov ontvang het. Dat hy daarmee kon bedoel het dat hy hierdie berig op 'n ander wyse ontvang het as die tradisie wat hy in 1 Korintiërs 15:3-5 aanhaal, kan 'n mens kwalik glo. Die meeste eksegete oordeel trouens ook so, al ondervind hulle baie moeite om te verklaar waarom Paulus sê dat hy die inligting van 'die Here' ontvang het.

Die vroeg-kerklike tradisiemateriaal kan natuurlik onder verskillende kategorieë tuisgebring word, afhangende van die funksie wat hulle in die kategese, verkondiging of liturgie van die vroegste geloofsgemeenskappe vervul het. Soos verwag kan word, word hulle egter nie deur almal eners getipeer nie. So onderskei byvoorbeeld Wengst (1967:2-3) tussen 'katechetische Formeln,' waaronder 'soteriologische' en 'Personsformeln.' en 'gottesdienstliche Rufe und Lieder,' waaronder 'Akklamationen' en 'Lieder', terwyl Dunn (1977:66-68) onderskei tussen 'kerygmatic, ethical, and church tradition'. Vir die doeleindes van hierdie studie is die kategorisering van die materiaal egter nie van belang nie. Wat wel van belang is, is dat ons redelike sekerheid moet hê oor wat wel as tradisiemateriaal beskou kan word, om dan van daaruit te probeer uitmaak hoe Paulus daarmee te werk gegaan het. En hoewel daar, soos reeds hierbo gemeld, nie konsensus is oor wat alles as voor-Paulinies beskou moet word nie, sal die oorgrote meerderheid saamstem dat die volgende met 'n hoë mate van sekerheid as voor-Paulinies onderskei kan word: God het sy Seun gestuur (Rom 8:3; Gal 4:4); Hy is as Godseun ingestel (Rom 1:3-4); is 'vir ons' oorgelewer (Rom 8:32; Gal 1:4; 2:20; vgl ook Ef 5:2, 25); het 'vir ons' gesterf (Rom 5:6, 8; 14:15; 2 Kor 5:14; 1 Tess 5:10; vgl 1 Kor 1:13; 8:11; Gal 2:21); is as soenmiddel daargestel (Rom 3:25); is uit die dood opgewek (Rom 10:9; 1 Kor 15:12; 1 Tess 1:10); is oorgelewer en opgewek (Rom 4:25); het gesterwe en opgestaan (1 Tess 4:14); het gesterwe, is begrawe, is opgewek en het verskyn (1 Kor 15:3-5); het Homself verneder en is verhoog (Flp 2:6-11; vgl 2

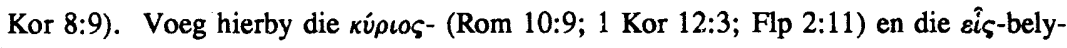
denisse (1 Kor 8:6) en die God-himne (Rom 11:33-36). En dan ook nog tradisie-stukke, soos dié oor die instelling van die nagmaal (1 Kor 11:24-25), oor wat die doop inhou ( $\mathrm{Gal} \mathrm{3:27-28)}$ en ander wat met meerdere of mindere konsensus as voor-Pauliniese formules beskou word (bv 1 Kor 6:11). 


\section{UITDRUKKINGS VAN GELOWIGE SELFVERSTAAN}

Hierdie belydenisse moet gesien word as pogings van die vroegste geloofsgemeenskappe om uitdrukking te gee aan hulle verstaan van die Christusgebeure asmede hulle persepsie van wat hierdie gebeure eksistensieel vir hulle ingehou het.

Dit beteken vanselfsprekend dat die formulering van die belydenisse nie die verkondiging voorafgegaan het nie, maar dat dit eers moontlik geword het as antwoord op die verkondiging. Dit kan immers ook nie anders nie, omdat belydenis alleen as antwoord

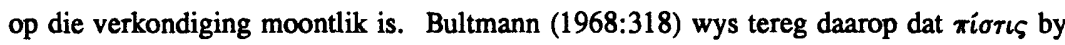

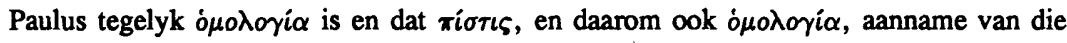

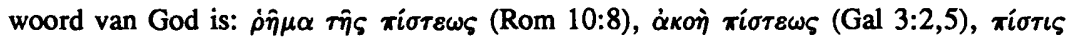

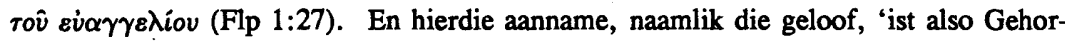
sam, Anerkennung, Bekenntnis' (Bultmann 1968:319). Natuurlik kan die meeste belydenisse op hulle beurt ook as 'n vorm van verkondiging beskou word omdat hulle onderskeidelik ' $n$ kernagtige verwoording van een of ander faset van die verkondiging is. Dat hulle antwoorde was waarmee op die verkondiging gereageer is, dui egter daarop dat hulle geloofsuitsprake van mense was wat deur die evangelie lewensveranderend getref is. Hulle was dus nie bedoel om algemene waarhede te konstateer of blote leerstellighede te wees nie. Die gelowiges wat hierdie belydenisse geformuleer en uitgespreek het, het klaarblyklik daarmee op kernagtige en kragtige wyse probeer sê wat die evangelie aan hulle gedoen het en hoe hulle die dinamiek van die evangelie op ' $n$ bepaalde stadium in hulle lewens ervaar het. Die belydenisse was dus tydsgebonde en nie bedoel om vir-ewig-gefikseerde formulerings te wees nie. Hulle was in die eerste plek uitdrukking van die geloofsbelewenisse van hierdie gelowiges en nie van hulle leer nie.

\section{NIE ONTOLOGIESE PROPOSISIES NIE}

Daar is bykans algemene instemming onder eksegete dat nie een van hierdie belydenisse ontologies van aard is of bedoel was om ontologiese proposisies te wees nie.

Dit verg nie besondere insig om raak te sien dat die bogenoemde formulerings sonder uitsondering een of ander faset van God se verlossingshandeling of van Christus se rol in die Christusgebeure verwoord of belig nie. Hulle is dus almal beskrywend van 'n gebeure en nie van 'n toestand, 'n syn of 'n status nie. Hulle is om hierdie rede soteriologiese en nie ontologiese formules nie. Selfs in 'n geval soos dié van die kúpıos-be- 
lydenis wat as 'n Christologiese formule getipeer kan word, is die soteriologiese dimensie op die voorgrond en vir geen oomblik buite die gesigsveld nie. In hierdie verband bly 'n opmerking van Bultmann nog so steekhoudend soos altyd. Dit is waaneer hy in opvolging van sy stelling dat in terme van die Pauliniese teologie elke uitspraak oor God tegelyk ook 'n uitspraak oor die mens is, en omgekeerd, die uiters belangrike opmerking maak dat ook Paulus se Christologie 'nicht das metaphysische Wesen Christi, sein Verhältnis zu Gott und seine "Naturen" spekulierend erörtert, sondern von ihm als dem redet, durch den Gott zum Heil von Welt und Mensch wirkt. ... und die paulinische Christologie ist zugleich Soteriologie (Bultmann 1968:192). Sou 'n mens daarom uit hierdie belydenisse wel ontologiese afleidings maak, sal jy in die lig van hulle oorweldigend soteriologiese inslag by hulle intensie verbyvra. Maar selfs as soteriologiese formules is hulle ook nie bedoel om geloofsproposisies te wees wat by die nasê daarvan outomaties dien as ' $\mathrm{n}$ vertoonvenster van ' $\mathrm{n}$ mens se Christenskap of van jou regsinnigheid nie. 'n Mens kry nêrens by Paulus die indruk dat hulle buite die funksie wat hulle as uitdrukkings van die kerugma of van gelowige selfverstaan vervul, enige funksie of betekenis het nie. Hulle kan derhalwe nie in die werklike sin van die woord belydenisse wees as hulle nie steeds eksistensieel bely word nie, as hulle nie telkens uitdrukking gee aan wat die gelowige beleef nie. Dit beteken byvoorbeeld dat in die belydenis 'Christus het vir ons gesterf', tegelyk die belydenis 'ons het saam met Christus gesterf' vervat is.

\section{NET VIR KERUGMATIESE EN PARANETIESE DOELEINDES BENUT}

Waar Paulus van hierdie belydenisse/liedere in sy briewe gebruik gemaak het, het hy dit deurgaans vir kerugmatiese/teologiese of paranetiese doeleindes aangewend.

Soos reeds hierbo gesê, is bykans elke belydenis hoewel in die eerste plek 'n antwoord op die verkondiging, self ook verkondiging in 'n neutedop. Om hierdie rede het die belydenisse hulle maklik geleen vir gebruik in die verdere uitdra van die evangelie of die oordra van teologiese gedagtes. Hulle is met ander woorde nie bloot om hulle eie onthalwe gesiteer nie, maar telkens gebruik om as ondersteuning vir 'n argument te dien of self 'n bepaalde kerugmatiese funksie te vervul. Hierdie feit kan maklik gekontroleer word in elke konteks waar Paulus hom van sodanige materiaal in sy argumentvoerings bedien het. Dit is gevolglik 'n onomstootlike feit dat ons geeneen van die genoemde geloofsprodukte van die vroegste geloofsgemeenskappe as erfstukke sou gehad het as dit nie was dat Paulus hulle vir sy verkondiging of paranese benut het nie. Dit geld natuurlik nie net vir Paulus nie, maar ook vir ander Nuwe-Testamentiese dokumente waarin van sodanige materiaal gebruik gemaak is. 


\section{NIE BEDOEL AS MAATSTAF VIR DIE VERKONDIGING NIE}

Daar is by Paulus geen aanduiding dat hy hierdie belydenisse/liedere beskou het as 'regte leer' wat kontrole oor die verkondiging of oor die lewe van die gemeente moes uitoefen nie.

Anders as wat dit die geval was in die tyd en omgewing van die Pastorale Briewe vind ons by Paulus nog nie 'n verwysing na ' $n$ leer wat as maatstaf vir lewe en verkondiging gedien het nie. In hierdie verband is Wegenast volkome gelyk te gee wanneer hy sê:

In den genannten Formeln [die formules wat deur Paulus gebruik is] liegt kein zeitloses und immer gleich gewesenes Glaubensprinzip vor und auch kein auf wenige Kernpunkte reduziertes Dogma im Sinne eines Glaubensgesetzes, zu dem man sich zu allen Zeiten fliehen könnte, sondern jeweilige geschichtliche Stellungnahme der Gemeinde, die in konkretem geschichtlichem Bezug steht.

(Wegenast 1962:51)

Dit is wel so dat Paulus teenoor die Korintiërs beklemtoon dat daar nie op 'n 'ander fondament' gebou mag word as wat gele is nie (1 Kor 3:11) en dat hulle moet vashou aan die evangelie 'soos dit aan hulle verkondig is' (1 Kor 15:1-2). Ook dat hy hulle dit verkwalik dat hulle so maklik daarmee genoeë neem as iemand 'n 'ander Jesus' aan hulle verkondig (2 Kor 11:4), en dat hy die Galasiërs dit verkwalik dat hulle so gou 'n 'ander evangelie' aanneem (Gal 1:6-9). Dit gaan hier egter duidelik nie om vas geformuleerde leerstellighede waarop die Korintiërs en Galasiërs die rug gedraai het nie, maar om die lewende en dinamiese verkondiging van die evangelie. Dat Paulus egter ook akkommoderend was en tot op groot hoogte vir ander opinies ruimte gelaat het, kan nie ontken word nie. Terwyl hy byvoorbeeld wel die verdeeldheid as gevolg van die partyskappe in Korinte skerp veroordeel, ontsê hy nie die partye hulle opinies nie, en in sy eie woorde het hy 'vir almal alles geword om sommige te red' (1 Kor 9:22). 'Paul is far from being under the illusion that even in his own communities everyone believes and thinks exactly as he does' (Bauer 1971:235).

In die na-Pauliniese situasie teen die einde van die eerste eeu het sake egter anders ontwikkel. So laat veral die Pastorale Briewe blyk dat in die tyd en omgewing waarin hierdie briewe ontstaan het, daar reeds 'n 'leer' tot stand gekom het wat volgens alle aanduidings veronderstel was om as norm vir die lewe en die verkondiging te dien. Dunn (1977:69) som die saak goed op met die opmerking: 'Evidently by the time the 
letters to Timothy and Titus were written (late first century?) a coherent body of tradition had become established to serve as a clearly defined touchstone of orthodoxy'. So lees ' $n$ mens in die Pastorale Briewe van 'die leer' ( $\delta\llcorner\delta \alpha \sigma \kappa \alpha \lambda i \alpha-1$ Tim 4:16; 6:1; 2

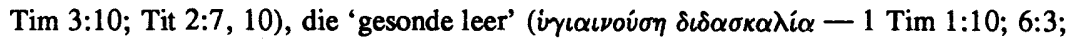
2 Tim 4:3; Tit 1:9; 2:1), die 'goeie leer' ( $\alpha \alpha \lambda \dot{\eta} \delta \iota \delta \alpha \sigma \kappa \alpha \lambda i \alpha-1$ Tim 4:6; 6:3), ge-

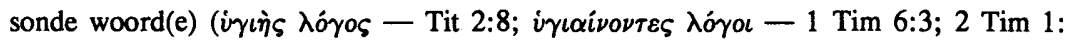
13), ensovoorts. Hiervan sê Dunn (1977:361) verder: 'The possibility of this tradition being (radically) recast or moulded into fresh formulations is nowhere envisaged, and indeed is almost certainly excluded'. In dieselfde trant maak Wegenast die opmerking dat die wyse waarop van die tradisie in die Pastorale Briewe gebruik gemaak word, toon ' $\mathrm{daB}$ der Verfasser unserer Briefe die Tradition als letzte und offenbarte Instanz versteht, der gegenüber keine Kritik, ja nicht einmal mehr eine Modifikation möglich ist' (Wegenast 1962:157). En volgens Bultmann geld dieselfde ook vir van die ander

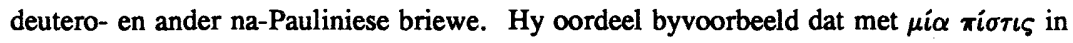

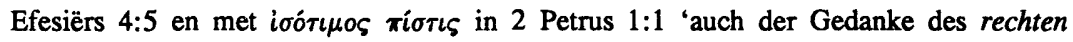
Bekenntnisses mitgedacht' is (Bultmann 1968:488). Dat die situasie ten tye van die ontstaan van hierdie briewe so ontwikkel het, is begryplik in die lig van die feit dat die institusionalisering van die kerk toe al betreklik ver gevorder het.

Hoewel ons dus met reg kan sê dat die gedagte van 'n belydenis of ' $n$ 'leer' as een of ander riglyn vir die verkondiging eers ' $n$ na-Pauliniese verkynsel in bepaalde kringe was, wil dit nogtans voorkom of dit ook nog nie gedurende hierdie 'vroeg-katolieke' periode tot 'n ortodokse reël ontwikkel het nie, soos Bauer (1971) reeds geruime tyd gelede aangetoon het. Bauer het naamlik aangetoon dat daar aanvanklik geen 'suiwer' vorm van Christendom was wat daarop kon aanspraak maak dat dit 'ortodoks' was in onderskeiding van ander wat as 'ketters' gekwalifiseer sou kon word nie. Elke groepering het sy eie aanspraak op regsinnigheid gemaak en die regverdiging van hierdie aanspraak het slegs afgehang van wie uiteindelik die leerstryd gewen het deur die sterkste invloed in die kerk uitgeoefen te kry of die sterkste magsbasis te bekom. Hieroor sê Bauer (1971:231) onder andere:

The form of Christian belief and life which was successful was that supported by the strongest organization - the form which was the most uniform and best suited for mass consumption - in spite of the fact that, in my judgement, for a long time after the close of the post-apostolic age the sum total of consciously orthodox and anti-heretical Christians was numerically inferior to that of the 'heretics'. 
Dit is ter ondersteuning van hierdie bydrae en standpunt van Bauer dat Dunn (1977:3) na die tweede-eeuse. Christendom verwys het as 'a very mixed bag' waarin daar geen eenduidige begrip was van wat onder ortodoks verstaan moet word nie, maar alleen verskillende vorms van Christendom wat gekompeteer het vir die lojaliteit van gelowiges. Hierdie waarneming word deur Bultmann bevestig wanneer hy daarop wys dat daar teen die einde van die eerste begin tweede eeu nog nie so iets as 'n vaste maatstaf of 'n outoritatiewe leerstelling bestaan het nie. En as dit selfs nog nie vir hierdie periode gegeld het nie, hoeveel minder sou dit vir die vroegste en Pauliniese periode kon geld? 'Am Anfang steht der Begriff des Glaubens, der die christliche Gemeinde von Juden und Heiden unterscheidet, nicht der Begriff der Rechtgläubigkeit, der mit seinem Korrelat, dem Begriff der Irrlehre, erst aus den Differenzen erwächst, die sich innerhalb der christlichen Gemeinden bilden' (Bultmann 1968:487; kyk ook Dunn 1977:17).

\section{DIE BELYDENISSE BY DIE VERKONDIGING AANGEPAS}

Omdat verkondiging by Paulus so 'n sentrale rol gespeel het en omdat hy belydenisse nie gesien het as onveranderlike gegewenhede nie, het hy nie gehuiwer om daaraan te verander of dit teologies aan te pas om dit vir sy verkondiging diensbaar te maak nie. Hy het dus nie verkondig aan die hand van die voorhande belydenisse nie, maar hulle eerder aan sy verkondiging ondergeskik gemaak.

Dit is eers wanneer ' $n$ mens die vraag stel na die wyse waarop Paulus van oorgelewerde belydenisse gebruik gemaak het, dat jy iets begin agterkom van die verhouding wat daar by hom tussen belydenis en verkondiging bestaan het. Daar moet egter in hierdie verband in die eerste plek gewys word op die probleem soos deur Wegenast (1962:51) verwoord, naamlik 'daß die einzelnen Bekenntnistraditionen, die Paulus in seinen Briefen anführt, durchaus nicht denselben Wortlaut haben, ja nicht einmal dieselben Aspekte, unter denen Jesus betrachtet und geglaubt wurde, zeitigen ....' Dit is om hierdie rede, maar ook omdat daar nie in elke geval met absolute sekerheid gesê kan word hoe die voor-Pauliniese formule daar uitgesien het nie, dat dit nie altyd maklik is om uit te maak waar ' $n$ mens met Pauliniese toevoegings of wysigings te make het nie. Dit kom 'n mens gou agter wanneer die opinies van eksegete betreffende sodanige moontlike toevoegings of veranderings met mekaar vergelyk word.

Daar is gevalle waar Paulus van bepaalde belydenisse gebruik gemaak het, waarskynlik sonder om wesenlik daaraan te verander, terwyl daar ander is wat hy beslis gewysig het om by sy teologie te pas. Hy het hulle dus nie as heilige koeie beskou wat 
onaangetas en ongewysig gelaat moes word nie. Hierdie feit is oortuigend bevestig, onder andere deur 'n ondersoek wat deur Tuckett gedoen is na die wyse waarop Paulus met die tradisie omgegaan het. Hy toon naamlik aan dat dit uit 1 Korintiërs 7 en 9 blyk dat Paulus hom selfs in die geval van die Jesustradisie vry gevoel het om op ' $n$ radikale wyse te interpreteer. '... Paul feels free not only to interpret traditions by adapting them; he also apparently feels free to reject some traditions altogether' (Tuckett 1991: 315). Volgens Tuckett (1991:316-321) was daar tweërlei maatstaf waarvolgens Paulus die tradisies herinterpreteer het, naamlik in die eerste plek die liefde, maar dan ook vryheid as 'n aspek van liefde. Die feit dat hy van die tradisies gebruik gemaak het, sê wel iets van die waarde wat hy aan hulle geheg het, maar hierdie waarde is alleen bepaal deur hulle bruikbaarheid vir die verkondiging van die Pauliniese evangelie. Hy het hulle dus nie gesiteer bloot om hulle as ' $t$ ware uit te stal of daarmee bo alle twyfel te bewys dat hy 'regsinnig' is nie. Hieruit blyk verder duidelik dat hy nie van oordeel was dat die verkondiging die belydenis moes dien nie, maar eerder die omgekeerde. Hierdie benadering en handelswyse is van besondere betekenis vir die vraag na die verhouding belydenis en verkondiging by Paulus, waarop hieronder verder ingegaan sal word.

Om enigsins ' $n$ idee te kry van hoe Paulus hom van hierdie belydenisse bedien het en hoe hy hulle vir die doeleindes van sy verkondiging aangepas het, is dit wenslik dat om aan ' $n$ paar van die bekendste sodanige gevalle aandag te gee. Die bedoeling hiermee is nie om op al die eksegetiese kwessies rakende die betrokke gevalle in te gaan nie, maar alleen om aan te toon in watter mate Paulus wel veranderend en aanpassend te werk gegaan het.

\subsection{Romeine 1:3-4}

Een van die bekendste sodanige gevalle is sonder twyfel Romeine 1:3-4. Daar is in kritiese geleerdheid konsensus daaroor dat ons hier te make het met 'n voor-Pauliniese, adopsiaanse Christologiese formule (kyk o a Kramer 1966:109; Wengst 1967:107; Conzelmann 1968:96; Schlier 1972:213; 1979:24; Käsemann 1974:9; Tuckett 1991:310; Schmithals 1994:17) wat deur Paulus in lyn met sy teologie gebring is deurdat hy dit op ' $n$ bepaalde wyse in die huidige konteks geïnorporeer het en daaraan toegevoeg het. Hy het die formule in lyn met sy teologie gebring deur in die eerste

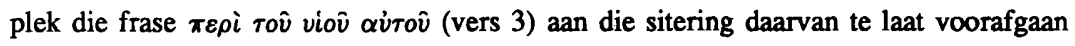
en in die tweede plek die woorde év $\delta v \nu \alpha ́ \mu \varepsilon \iota$ (vers 4) daaraan toe te voeg. Hoewel daar nie eenstemmigheid is oor wat alles deur hom bygevoeg is nie, is die oorgrote meerderheid van oortuiging dat minstens die woorde $\dot{\varepsilon} \nu \delta \nu \alpha \dot{\alpha} \mu \varepsilon \iota$ van Paulus se hand is (kyk o a Wegenast 1962:71; Wengst 1967:106; Schlier 1972:209-10; 1979:24; Wilckens 1978: 
65; Tuckett 1991:310; Kramer 1966:110 is onseker). Bultmann (1968:52) het geoordeel dat ook die twee $\kappa \alpha \tau \alpha$-frases deur Paulus bygevoeg is, maar hy het nie veel steun daarvoor gevind nie (wel by Wengst 1967:105-106; maar nie by bv Wegenast 1962:71; Kramer 1966:109; Hahn 1969:247; Schlier 1972:211; Wilckens 1978:57-58 nie). Indien die waarneming korrek is dat Paulus die woorde $\dot{\varepsilon} \nu \delta \nu \dot{\alpha} \mu \varepsilon \iota$ bygevoeg het, en alles dui daarop dat dit wel die geval is, kan 'n mens nie anders as om hiervan te moet aflei dat hy hiermee gepoog het om die formule van sy adopsiaanse karakter te stroop nie. Hierdie adopsiaanse karakter, naamlik dat Christus eers sedert of op grond van sy opstanding as Seun van God ingestel is, was vir hom 'durchaus fremd' (Wilckens 1978: 58) en onversoenbaar met sy preëksistensie-Christologie, soos onder andere uitgedruk deur sy uitsprake dat God sy Seun 'gestuur' het (Rom 8:3; Gal 4:4; vgl ook Flp 2:6-7; 2 Kor 8:9). Die oorspronklike formule het na alle waarskynlikheid in sy mees basiese vorm bloot gestel dat Jesus uit die geslag van Dawid was en dat Hy kragtens sy opstanding as Seun van God ingestel of geïntroniseer is. Hierteenoor het Paulus enersyds

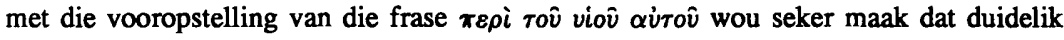
verstaan sal word dat Christus reeds preëksistent Seun van God was en dit daarom nie eers sedert sy opstanding geword het nie. Andersyds het hy met die toevoeging van die woorde $\dot{\varepsilon} \nu \delta \nu \nu \alpha \dot{\mu \varepsilon l}$ probeer verseker dat verstaan sal word dat omdat Christus reeds preëksistent Seun van God was, hy by sy opstanding alleen nog Seun van God 'met mag' kon word, dit wil sê tot 'n hoër magsposisie verhoog kon word. In verband met

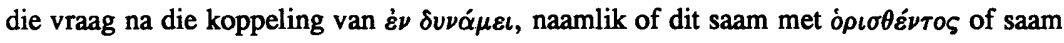
met vioû $\Theta \varepsilon o \hat{v}$ gelees moet word, lyk dit nie geregverdig om vir eersgenoemde te besluit nie. Die keuse vir eersgenoemde blyk eerder 'n poging te wees om te ontkom aan die gedagte dat Christus dalk ná sy opstanding tot 'n hoër status verhoog is as wat $\mathrm{Hy}$ voorheen beklee het en dat die formule dan nog steeds 'n element van adopsianisme of subordinasie sou bevat. Die meeste eksegete stem dan ook saam dat die keuse vir laasgenoemde moontlikheid die aangewese is, en dit om verskeie redes waarop dit nie nodig is om verder hier in te gaan nie.

Daar dien egter verder op gewys te word dat daar geleerdes is wat van oortuiging is dat die formule reeds ' $n$ ontwikkeling deurgemaak het voordat dit deur Paulus benut is. As voorbeeld kan verwys word na die studie van Schlier (1972) waarvolgens twee voorstadia van die formule geidentifiseer is. Schlier onderskei as eerste stadium 'n Joods-Christelike 'twee-stadia' Christologie waarin die tweede deel van die formule nie in teenstelling met die eerste staan nie en waarin gestel word dat Jesus wat reeds in sy aardse bestaan Messias was, kragtens sy opstanding tot hemelse Messias, tot Seun van God geïntroniseer is. As tweede stadium ontwikkel daar vervolgens in HellenistiesJoodse kring uit die 'twee-stadia' Christologie 'n teenstelling wat met die frases $\kappa \alpha \tau \grave{\alpha}$ 
$\sigma \dot{\alpha} \rho \kappa \alpha-\kappa \alpha \tau \dot{\alpha} \pi \nu \varepsilon \hat{v} \mu \alpha \dot{\alpha} \gamma \iota \omega \sigma \dot{v} \nu \eta \varsigma$ uitgedruk word. Nou word van Jesus gesê dat Hy, wat sy aardse herkoms betref, uit die geslag van Dawid was, maar kragtens die $\delta o ́ \xi \alpha$ wat in sy opstanding werksaam was, in sy hemelse bestaanswyse tot Seun van God geword het. Die gewig van die formule lê nou meer op die tweede gedeelte en hier word reeds wegbeweeg van die adopsiaanse gedagte af. Die derde stadium is dit wat Paulus daarvan gemaak het. Hier is Christus van ewigheid af en wesenlik die Seun van God en word Hy kragtens sy opstanding die Seun van God 'met mag', word Hy Kúplos. Vanuit hierdie gesigspunt gesien, word die eerste deel van die formule tot 'n uitspraak oor sy menswording (kyk Schlier 1972:215-216). Of sake inderdaad so verloop het soos Schlier vermoed, is nie maklik uit te maak nie. Of dit wel die geval was, verander egter nie daaraan dat Paulus van 'n bestaande formule gebruik gemaak en vir sy doel aangepas het nie. Hy het klaarblyklik die formule bruikbaar gevind om as Christologiese basis vir sy evangelie te dien, maar nie gehuiwer om so daaraan te verander dat dit versoenbaar met en diensbaar vir sy verstaan van die Christusgebeure kon wees nie.

\subsection{Romeine 3:25}

Bultmann (1968:49) was die eerste om ten opsigte van Romeine 3:24v op te merk dat ons hier te make het met 'n tradisionele formulering waarby Paulus aangesluit het en wat hy van sy eie teologiese toevoegings voorsien het. Volgens Bultmann het die tradisionele formulering bestaan uit die hele vers 24 en 25 , plus die frase $\dot{\varepsilon} \nu \tau \hat{n} \dot{\alpha} \nu 0 x \hat{n}$ rôे $\Theta \varepsilon o \hat{v}$ aan die begin van vers 26 , terwyl hy as Pauliniese toevoegings beskou het die

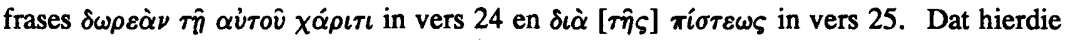
gedeelte 'n voor-Pauliniese formulering is, grond Bultmann op die volgende argumente: ten eerste word Christus net hier by Paulus as i $\lambda \alpha \sigma \tau^{\prime}$ ó praat hy, behalwe in Romeine 5:9 en in 1 Korintiërs 10:16;11:25, 27, waar hy weer

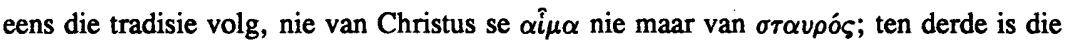
voorstelling van God se $\delta \iota \alpha \iota \sigma u ́ v \eta$ wat vereis dat daar vir die voorheen gedane sondes versoening gedoen moet word, vir Paulus vreemd. Bultmann is sedertdien hierin deur verskeie vakgenote hierin gevolg. Die meeste van hulle beskou egter, met enkele variasies, net vers 25 as 'n voor-Pauliniese formulering (so bv Conzelmann 1968:187; Wilckens 1978:190; Dunn 1988:181; Longenecker 1993:478-480; Schmithals 1994: 100) en nie ook vers 24 nie (so wel Käsemann 1960a:96; Wegenast 1962:76). Soos verwag kan word, is nie al hierdie eksegete dit eens oor wat as Pauliniese toevoegings beskou moet word nie, hoewel die oorgrote meerderheid nie daaroor twyfel het dat $\delta i \grave{\alpha}$

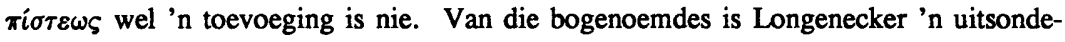
ring deurdat hy oordeel dat hierdie woorde nie verstaan moet word as verwysende na 
die geloof van die Christen nie maar na die 'faithfulness' van Jesus Christus. Longenecker se standpunt is verteenwoordigend van 'n oortuiging wat toenemend gepropa-

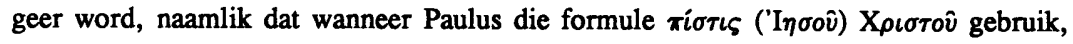
hy nie daarmee 'n objektiewe nie maar 'n subjektiewe genitief bedoel en dat dit derhalwe verstaan moet word as verwysende na Christus se geloof of getrouheid en nie na geloof in Christus nie. Terwyl dit nie moontlik is om binne hierdie bestek op Longenecker se standpunt in te gaan nie, moet nogtans daarop gewys word dat hoewel dit grammaties nie onmoontlik is om die teks so te lees nie, dit baie onwaarskynlik lyk in hierdie konteks waarin die klem so oorweldigend gelê word op die geloof as die enigste wyse waarop 'n mens in die regte verhouding met God gestel kan word (vgl Wilckens 1978:194).

Wat sou nou Paulus se oogmerk gewees het met die byvoeging van hierdie woorde? Die vermoede bestaan dat hierdie tradisiestuk in 'n Joods-Christelike kring ontstaan het (kyk Käsemann 1960a; Wegenast 1962:79; Dunn 1988:181). En.volgens Käsemann (1960a:100) was dit vir Paulus belangrik en bruikbaar 'weil sie das Heilsereignis als durch Christi Tod begründete Rechtfertigung beschrieb'. Terwyl dit vanselfsprekend is dat Paulus die formulering as belangrik vir sy argument beskou het, is dit ook duidelik dat dit na sy oordeel nie genoeg gesê het nie. Daarom het hy ook in hierdie geval ingegryp om die formulering in lyn met sy teologie te bring. Dunn (1988:181) gaan waarskynlik te ver deur te beweer dat Paulus xiotıs toegevoeg het om as korreksie te dien vir die Joodse beskouing oor die kultus as selfwerkend. Käsemann moet eerder gelyk gegee word wanneer hy sê dat Paulus by die sola gratia wat reeds in die formulering aanwesig was, die sola fide gevoeg het nie net deur vers 26 parallel naas vers 25 te plaas nie, maar ook deur dit 'höchst gewaltsam und störend' deur mid-

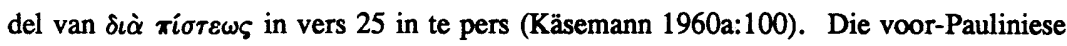
Joods-Christelike formulering het dus tot uitdrukking probeer bring dat God se verbondstrou stand gehou het deurdat Hy Jesus Christus as 'n soenmiddel daargestel het om die sonde van die verlede uit te delg. Hiermee is egter nog net iets gesê oor die (ver)soeningshandeling ( $i \lambda \alpha \dot{\sigma} \sigma \kappa o \mu \alpha \iota$ in onderskeiding van $\kappa \alpha \tau \alpha \lambda \lambda \alpha \dot{\sigma} \sigma \sigma \omega$ ) van God en nie oor die wyse waarop die sondaars vir wie Hy Christus as soenmiddel daargestel het, daaraan deel kry nie. Dit het in terme van die Paulusteologie vanselfsprekend die toevoeging van $\delta i \grave{\alpha} \pi i \sigma \tau \varepsilon \omega \varsigma$ genoodsaak om so aan die bestaande formulering 'n eg Pauliniese karakter te verleen, naamlik dat die vryspraak en versoening wat deur die dood van Christus bewerkstellig is, alleen deur geloof verkry kan word. Daar is egter ook 'n ander dimensie wat deur middel van $\delta i \grave{\alpha} \pi i \sigma \tau \varepsilon \omega \varsigma$ st die formulering toegevoeg word. Dit is die universele dimensie van die geloof wat oor partikuliere grense heen die heil in Jesus Christus vir alle mense toeganklik maak. Dit is op grond hiervan dat 
Käsemann (1960a:100) stel dat vers 26 'n korreksie op vers 25 is omdat Paulus daarmee sê dat God se geregtigheid nie die herstel van die ou verbond is nie maar iets nuuts is wat Hy vir alle mense tot stand gebring het (kyk ook Schmithals 1994:101).

Om saam te vat, Paulus het enersyds van hierdie formulering gebruik gemaak omdat dit tot op sekere hoogte legitieme Christusverkondiging bevat het. Andersyds het hy met die aanpassing daarvan by die konteks waarin hy dit aangewend het, tweërlei oogmerk gehad. Eerstens het hy met die toevoeging(s) 'n teologiese basis voorsien vir wat hy met soveel klem in hierdie perikoop betoog, naamlik dat 'n mens die (ver)soening wat God deur Christus bewerk het, alleen deur geloof tot jou eie kan maak. Tweedens het hy daardeur buite diskussie gestel dat daar aan die (ver)soening universeel deel gekry kan word, juis omdat alle mense dit deur geloof deelagtig kan word sonder om op grond van 'n bepaalde sekulêre verbondenheid daarvoor te moet kwalifiseer. 'n Mens kan die wyse waarop Paulus in hierdie konteks andermaal met 'n belydenistradisie omgegaan het, kwalik beter beskrywe as met die volgende opmerking van Wegenast (1962:79): 'Es ist also keinesfalls so, daB Paulus in der ihm zugekommenen Tradition den Text sieht, dessen Diener er als Ausleger auch in der Interpretation ist, sondern so, daß über der Tradition sein Verständnis der Heilsbedeutung Jesu als Norm steht'.

\subsection{Filippense 2:6-11}

Aan seker geen ander voor-Pauliniese tradisie-eenheid is al deur middel van wetenskaplike ondersoeke van allerlei aard en omvang soveel aandag bestee as aan die bekende Christushimne in Filippense 2:6-11 nie. Daar word allerweë aanvaar dat die werklik indringende en gespesialiseerde bestudering van hierdie himne ingelui is deur die studie wat in 1928 deur Lohmeyer onderneem is. Daarin het hy eerstens met die teorie na vore gekom dat die himne 'n voor-Pauliniese komposisie was. Hy het sy oortuiging enersyds daarop gegrond dat die himne nie alleen ver bo die paranetiese konteks waarin dit geplaas is, uitbeweeg nie maar ook slegs losweg daarmee verbind is. Andersyds het hy geoordeel dat 'die Strenge der strophischen Bildung und die bis ins Feinste durchgeführte Gliederung' sowel as die 'Sprachgebrauch' van die himne die moontlikheid uitsluit dat dit van Paulus se hand kon wees (Lohmeyer 1961:8). Maar hiermee saam het hy ook die oortuiging uitgespreek dat die woorde $\theta \alpha \nu \alpha ́$ tov $\delta \grave{\varepsilon}$

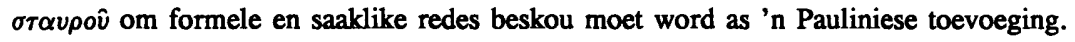
Formeel pas hierdie woorde nie in by Lohmeyer se indeling van die himne in ses strofes met drie min of meer ewe lang reëls elk nie, aangesien dit die laaste reël van die derde strofe tot so 'n mate verleng dat dit die balans van die strofe in vergelyking met die ander versteur (kyk Lohmeyer 1961:5-6). Saaklik vervang hierdie woorde die 
himne se verstaan van die dood van Jesus met Paulus se verstaan daarvan. Die himne se verstaan van Jesus se dood, wat ook aangetref word in die Johannese tradisie en in die Hebreërbrief, is dat dit 'n Goddelike raaisel is waarin egter tegelyk die wonder van die opstanding opgesluit lê. In Paulus se verstaan van hierdie tipe dood word klem gelê op die aard daarvan, naamlik dat dit beskou is as die ergste ergernis en die dwaasste dwaasheid (1 Kor 1:23). Hierdeur, so het Lohmeyer (1961:45) geoordeel, wou Paulus mér maak van die dood van Jesus as die lied se blote noem daarvan en wou hy ook die 'Größe der vorbildlichen Demut Christi' verhoog.

'n Verdere ondersoek van besondere belang wat sedert dié van Lohmeyer onderneem is, is die studie van Käsemann (1960b) wat eweneens as van baanbrekende betekenis beskou word. Käsemann het, anders as wat tot op daardie -stadium oorwegend die geval was, met ' $n$ beroep op Barth en Kögel aangetoon het dat die himne se skopus nie in die daarstelling van 'n etiese voorbeeld geleë is nie maar in die daarstelling van 'n heilsdaad met kosmiese dimensies. 'Der Anthropos bleibt himmlisches Wesen und kann darum gar nicht Vorbild werden. Er offenbart Gehorsam, aber er macht ihn nicht zur Imitation vor. Er ist Urbild, nicht Vorbild, um es zugespitzt zu sagen' (Käsemann 1960b:81). Dit is dan ook op grond van hierdie cortuiging dat Käsemann, weer eens in aansluiting by Kögel, van oordeel is dat die sin in vers 5, wat

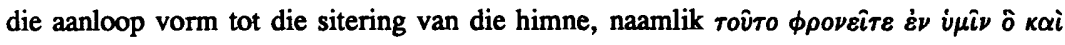
$\dot{\varepsilon} \nu$ X soos $\hat{\eta} \nu$ nie. Dit hou volgens hom in dat $\dot{\varepsilon} \nu$ X $\rho \iota \tau \hat{\varphi}$ 'nicht paradigmatisch, sondern als die bei Paulus so häufige technische Formel mit dem Sinn "im Bereich des Christus" verstanden wird' (Käsemann 1960b:57). Dit gaan dus hier nie om 'n voorbeeldmotief nie maar om ' $n$ ingesteldheid van gehoorsaam te wees. 'Hier wird bezeugt, daB die Welt dem Gehorsamen gehört und er Herr ist, damit wir gehorsam würden. Gehorsam werden wir jedoch nicht durch ein Vorbild, sondern durch das Wort, das uns als Thm gehörig bezeugt' (Käsemann 1960b:95). Die gelowige word opgeroep tot $\tau \alpha \pi \varepsilon \iota \nu \circ \phi \rho \sigma i v \eta \eta$ maar dan nie as navolging van Christus se voorbeeld nie, maar op grond van die eskatologiese 'in Christus' situasie wat Christus deur sy gehoorsaamheid bewerkstellig het (Käsemann 1960b:94).

Sedert Lohmeyer en Käsemann se studies het die insig dat die himne minstens 'n eie besondere vorm vertoon wat dit duidelik onderskei van die konteks waarin dit voorkom, bykans algemene aanvaarding gevind. Martin (1983:xvi) merk hieroor tereg op: '.. the poetic or hymnic character of the verses remains a virtual consensus in recent debate, with no serious attempt to overturn it'. Hierbenewens het die sterk stimulus wat daar van hierdie studies uitgegaan het, soveel ondersoeke na hierdie himne ten gevolg gehad dat die literatuur daaroor reeds onoorsigtelik geword het (kyk o a 
Martin 1983:15-96; Nagata 1981:9-87; Hawthorne 1983:76-77 vir 'n oorsig), hoewel dit opvallend is dat daar meer as twee dekades verloop het sedert daar laas 'n betreklik uitvoerige studie soos dié van Martin onderneem is. Terwyl daar bykans universele konsensus oor die poëtiese karakter van die verse bestaan, al word daar aansienlik oor die formele struktuur daarvan verskil, kan dieselfde nie gesê word van die gedagte dat dit 'n voor-Pauliniese himne is wat deur Paulus oorgeneem en vir die doeleindes van sy paranese in die Filippensebrief gebruik en aangepas is nie (kyk Martin 1983:61). En tog kan sonder vrees vir teenspraak gesê word dat die oorgrote meerderheid van navorsers die voor-Pauliniese oorsprong van die himne as 'n bewese feit aanvaar. In die geval van die beweerde toevoegings tot die himne is daar egter meer meningsverskil as in die geval van die vraag na die voor-Pauliniese outeurskap. By verre die meerderheid navorsers (o a Wengst 1967:140; Deichgräber 1967:125; Conzelmann 1968:99; Gnilka 1968:124; Barth 1979:41; Nagata 1981:352; Müller 1988:21; 1993:105; Silva 1992: 122; Schmithals 1994:93) stem nietemin saam dat minstens die woorde $\theta \alpha \nu \alpha ́$ tov $\delta \check{\varepsilon}$

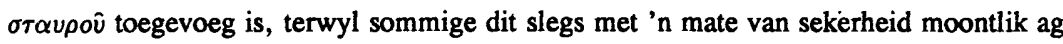
(bv Martin 1983:222) en 'n paar van oordeel is dat ook hierdie frase voor-Paulinies is (o a Hofius 1976:3-17; Mengel 1982:247; Hawthorne 1983:77). Hofius byvoorbeeld het moeite gedoen om teenoor Lohmeyer en ander te probeer aantoon dat hierdie woorde formeel én saaklik as behorende tot die oorspronklike vorm van die himne beskou moet word. Aan die hand van voorbeelde in Ou-Testamentiese liedere oordeel hy dat die frase $\theta \alpha \nu \alpha \dot{\alpha} \tau o v \delta \grave{\varepsilon} \sigma \tau \alpha \nu \rho o v$ op formele gronde beskou moet word as die poëtiese stylfiguur bekend as anadiplosis, en verklaar dan: 'Kein Formgesetz poetischer Gestaltung ist verletzt, wenn die 1. Strophe des Christusliedes mit einer Anadiplosis endet' (Hofius 1976:12, kyk ook 56). Wat die saaklike sy betref, oordeel hy dat die himne selfs sonder hierdie frase Christus se dood as kruisdood verstaan het en 'daß im Hymnus eine feste Anschauung von der Heilsbedeutung des Sterbens Jesu bereits vorausgesetzt ist' (Hofius 1976:17). Vir hierdie interpretasie steun Hofius (1976:7074) verder, in navolging van Jeremias, baie sterk op wat hy beskou as die duidelik aanwysbare Ou-Testamentiese agtergronde van hierdie himne en dan veral die gesindheid, optrede en lotgevalle van die Ebed Jahwe van Jesaja 53. Hiervolgens sou die 'toevoeging' dus in werklikheid nie nodig gewees het nie, maar vorm dit as anadiplosis by die

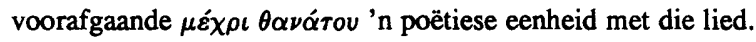

Hofius se standpunt het baie min steun gekry (kyk Martin 1983:xvi). En so kon

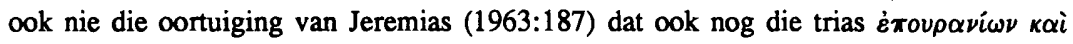

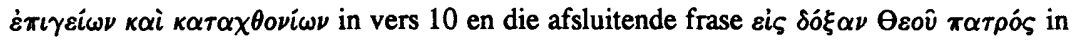
vers 11 (kyk Barth 1979:41) as Pauliniese toevoegings beskou moet word, noemenswaardige ondersteuning verwerf nie. Wat Hofius betref, moet daarop gewys word dat 


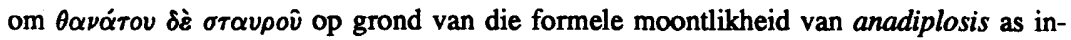
tegrerende deel van die oorspronklike lied te verklaar, nie as totaal uitgesluit beskou hoef te word nie, hoewel dit eenvoudig nie oortuigend genoeg is nie. Die eintlike probleem met sy standpunt is egter gelee in sy beskouing soos verwoord in sy reeds genoemde stelling ' $\mathrm{daB}$ im Hymnus eine feste Anschauung von der Heilsbedeutung des Sterbens Jesu bereits vorausgesetzt ist' (Hofius 1976:17). By dié wat die voorPauliniese oorsprong van die lied aanvaar, is die argument juis dat indien 'n mens die woorde oor die kruisdood skrap, daar niks oorbly wat daarop dui dat die dood wat hier ter sprake is, iets meer inhou as dat dit verwys na die laagste punt van vernedering van die figuur waaroor die himne handel nie. Soos hierbo gemeld is, het reeds Lohmeyer geoordeel dat die dood van hierdie figuur deur die himne anders verstaan is as wat met

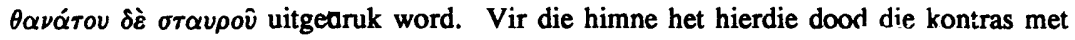
die Goddelikheid van hierdie figuur wat reeds tot uitdrukking gekom het in sy menswording en aanneming van slaafwees, tot die uiterste gevoer, en daarom was die aard van hierdie dood vir die himne 'gleichgültig' (Lohmeyer 1961:44; kyk ook Müller 1993:105). So gesien, word daar in die himne dus nie alleen niks oor die omstandighede of die aard van die dood van hierdie figuur gesê nie, sy dood word ook nie hanteer asof dit van besondere of van soteriologie _ betekenis was nie (so tereg o a Wengst 1967:140; Beare 1969:85; Nagata 1981:259, 351; Müller 1988:21; Schmithals 1994: 93; vgl Silva 1992:122).

Om te kom by die saak waarom dit in hierdie studie gaan, is daar twee vrae waarop 'n antwoord gevind sal moet word. Die eerste is die vraag na die rede vir die

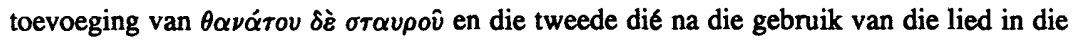
konteks waarin dit voorkom. Wat die eerste vraag betref, kan 'n mens kwalik anders as om saam te stem dat Paulus hom klaarblyklik nie kon vereenselwig met die rol wat die himne aan die dood van Christus toegeken het nie. Enersyds het die himne niks gesê oor die aard van hierdie dood, naamlik dat dit 'n 'skanddood' was nie. Deur die

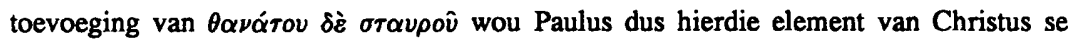
dood teenoor die Filippense beklemtoon. In die woorde van Martin (1983:221) sou dit vir hulle wat in 'n Romeinse stad geleef het die beklemtoning wees van 'the abject degradation of Christ's lowly obedience, and drive home the lesson that his identification with men reached the lowest rung of the ladder'. Andersyds kon daar nie uit die bewoording van die himne afgelees word dat hierdie dood soteriologiese betekenis gehad het nie. Daarom was dit vanselfsprekend dat Paulus op die basis van sy theologia crucis daaraan 'n soteriologiese dimensie sou verleen deur middel van sy genoemde toevoeging. Hiermee is niks verander aan die gang van die gebeure in die himne, naamlik preëksistensie - menswording - dood - verhoging nie, die dood maak net nie meer 'n ongekwalifiseerde komponent daarvan uit nie. 
Benewens die talle eksegetiese probleme wat hierdie himne tot dusver in die geskiedenis van die navorsing opgelewer het, was een van die moeilikste beantwoordbare vrae telkens ook die vraag na die oorspronklike Sitz im Leben daarvan. As deel van die 'große Schwierigkeiten' wat die himne omgewe, het dit byvoorbeeld vir Bomkamm (1970:184) laat vra: 'Ist er eigentlich ein Weihnachts- und Epiphaniastext oder ein Passions-, ein Oster- und Himmelfahrtstext?' Of het dit by die bediening van die doop of die viering van die nagmaal of gewoon in die liturgie gefunksioneer (kyk Martin 1983:287-311)? Dit is duidelik dat daar nog geen algemeen aanvaarde antwoord op hierdie vraag gevind kon word nie, en waarskynlik sal dit ook nooit gevind word nie. Vir die doeleindes van hierdie studie is dit egter ook nie nodig om in besonderhede daarop te moet ingaan nie. Wat wel nodig is, is dat daarvan kennis geneem moet word dat daar geen aanduiding is dat die himne tot op die stadium dat Paulus dit in sy Filippensebrief benut het, in paranetiese kontekste gefunksioneer het nie.

Hierdie feit maak dit soveel moeiliker om te verklaar waarom Paulus 'n himne wat Christus se selfvernedering en verhoging beskryf het en wat hy ook nog van 'n soteriologiese dimensie voorsien het, vir die doeleindes van sy paranese gebruik het. Hoewel daar nog steeds mense is wat die sogenaamde 'etiese interpretasie' voorstaan en oordeel dat Paulus vanuit paradigmatiese oorwegings die gehoorsaamheid en selfvernedering van Christus hier as 'n navolgenswaardige voorbeeld aan die Filippense wou voorhou, het daar sedert Käsemann se bydrae toenemende steun na vore gekom vir sy standpunt dat dit nie Paulus se intensie was nie. Met ander woorde dit wil voorkom dat

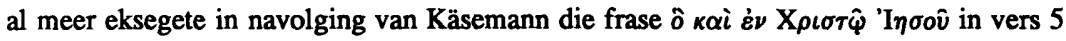
verstaan as verwysende na die situasie van 'in Christus' te wees of met Hom verbonde te wees, en om dan as ontbrekende werkwoord in die res van die sin фpoveite of

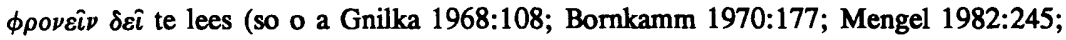
Martin 1983:288; Silva 1992:109; Müller 1993:90). Dit hou in dat тoûтo in die eerste deel van die sin nie gelees moet word as verwysende na wat in die himne ter sprake gaan kom nie, maar as terugverwysend na wat in verse 1-4 ter sprake was. So gesien, sou 'n mens vers 5 kon weergee met iets soos: 'Tree so (soos in 1-4 gestel) teenoor mekaar op soos dit pas by mense wat in verbondenheid met Christus lewe'. Of soos Martin (1983:288) dit kortweg stel: 'Act as befits those who are in Christ Jesus'. Die sterkste beswaar teen hierdie interpretasie en weergawe is dat om die tweede sinsdeel

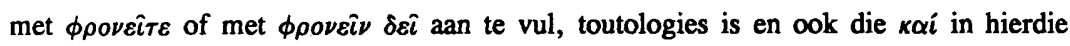
sinsdeel oorbodig maak (kyk Deichgräber 1967:192; Nagata 1981:345-347). Hoewel hierdie beswaar nie goedskiks van die tafel gevee kan word nie, neem dit nog nie weg dat die sinskonstruksie van vers 5 probleme skep nie. 
Hoe ons ook al die genoemde sinsdeel interpreteer, feit bly dat Paulus 'n niesoteriologiese en nie-etiese Christushimne by sy teologie angepas het en hier vir paranetiese doeleindes aangewend het. Waarom hy die himne vir hierdie doel bruikbaar gevind het, is nie so voor die hand liggend nie. Kraftchick (1993:3) het die mening uitgespreek dat dieselfde meganisme wat metafore skep, naamlik die ooreenkoms/verskil-struktuur wat inherent aan 'n metafoor is, Paulus in staat gestel het om die nie-etiese himne vir etiese doeleindes te gebruik sonder dat die teologiese integriteit daarvan verlore gegaan het. Dit is sonder twyfel so dat al is die himne op watter wyse ook al vir die paranese diensbaar gemaak, dit daardeur niks aan teologiese integriteit ingeboet het nie. Dit behou dus 'n eie teologiese selfstandigheid te midde van die konteks waarin dit geplaas is. Nadat dit alles gesê is, bly die vraag nog of Paulus hoegenaamd nie die intensie gehad het dat die selfvernedering en die gehoorsaamheid wat in die himne ter sprake is op een of ander wyse die Filippense tot soortgelyke optrede moes aanspoor nie. Is Nagata (1981:249) nie miskien reg as hy sê dat daar nie so skerp onderskei behoort te word tussen die etiese en soteriologiese interpretasie nie? Dit lyk of Käsemann (1960b:95) met die volgende opmerking self nie die etiese volledig uitsluit nie: 'Hier wird bezeugt, daß die Welt dem Gehorsamen gehört und er Herr ist damit wir gehorsam würden'. Indien 'n mens moet aanvaar dat die gebruikmaking van die himne in hierdie paranetiese konteks hoegenaamd nie bedoel was om tot etiese optrede op te roep nie, sal die teenwoordigheid daarvan in hierdie konteks streng gesproke as onverklaarbaar beskou moet word. Maar dan moet onmiddellik hieraan toegevoeg word dat om die lied uitsluitlik in paradigmatiese terme te interpreteer, nie rekening hou met die primêr soteriologiese karakter daarvan nie en dus by die intensie daarvan verbyvra.

Wat ten slotte uit die voorgaande bespreking geblyk het, is dat Paulus ook in hierdie geval getoon het dat hy van tradisiemateriaal gebruik gemaak het waar en wanneer dit van nut kon wees vir sy teologiese argumentvoering en dat hy dit vir die doeleindes van sy argument na goeddunke aangepas het. Hoewel die himne gewis vir hom 'n bepaalde gewig moet gedra het, het hy dus ook nie in hierdie geval gehuiwer om dit so te wysig dat dit minstens op een punt ingrypend anders oor Christus gepraat het nie. Tereg sê Wegenast (1962:90; my kursivering) in hierdie verband: 'Das an unserer Stelle zitierte Lied besitzt zwar im Zusammenhang der paulinischen Gedankenführung ein wesentliches Gewicht, doch ist es auf keinen Fall unveränderliche Basis der Verkündigung des Paulus'. 


\section{SLOTOPMERKING}

Daar kon met hierdie studie ongelukkig net aan die hand van enkele voorbeelde geillustreer word hoe Paulus met beskikbare tradisiemateriaal omgegaan het. Dit behoort egter voldoende bewys te wees vir die tese dat hy nie alleen vryelik en dikwels van sodanige materiaal gebruik gemaak het nie, maar ook dat hy hom die vryheid veroorloof het om dit aan te wend en daaraan te verander soos hy dit goed geag het en dit sy oogmerk met verkondiging of paranese die beste kon dien. Die blote feit dat hy van sodanige materiaal gebruik gemaak het, is van besliste belang, want dit dui daarop dat hy wel 'n bepaalde waarde daaraan geheg het en van oortuiging was dat hy daamee aan oortuigingskrag kon wen. Maar dit het ook duidelik geword dat hy op geen stadium van oordeel was dat hierdie materiaal van verhewe en onveranderlike status was en met ' $n$ gesag beklee was wat as voorskrywend vir sy verkondiging of teologiese denke beskou moes word nie. Ons kry by hom niks daarvan om die corlewering van 'n tradisiestuk te verseker of die bewoording daarvan te bewaar nie. Ook nie dat hy onder die indruk was dat hy eers deur die aanvaarding van 'n bepaalde tradisie of leerstuk vir die uitoefening van sy apostelskap bevoeg sou word nie (kyk Wegenast 1962:92). Sy omgang met hierdie materiaal was ad hoc en funksioneel omdat hy homself nie gesien het as 'n (oor)draer van tradisies nie maar as 'n verkondiger van die evangelie soos hy dit verstaan het en in elke nuwe situasie moes laat spreek. 'n Mens kry daarom nêrens die indruk dat hy hom verplig geag het om van hierdie materiaal gebruik te maak nie. Sy aanwending daarvan was spontaan. Hy kon só met hierdie materiaal omgaan omdat dit vir hom niks anders was as verwoordings van wat in die geloof eksistensieel ervaar is en telkens weer ervaar moes word nie. Die wyse waarop hy dit aangewend het, het op die basis van wat daarin verwoord is, telkens nuwe verwoordings, nuwe tekste, geword soos dit nodig geword het in elke nuwe situasie. Dit is ook heeltemal begryplik omdat die verkondiging nie vór en lós van die situasie waarin dit moet tref, in vaste, onveranderlike formules gegiet kan word nie. Dit beteken natuurlik nie dat Paulus hierdie materiaal nie gesien het as pogings tot die verwoording van basiese waarhede nie. Maar hulle was vir hom niks meer as dit nie en daarom het hy hulle nuut laat spreek deur die wyse waarop hy hulle hanteer het.

'n Laaste vraag wat nog beantwoord moet word, is wat die konsekwensie van die bevindings van hierdie studie is vir die vraag na die verhouding verkondiging en belydenis in die kerklike praktyk van vandag. Om mee te begin, kan verwys word na die volgende baie ter saaklike stelling van Tuckett (1991:310): 'Christian theology and praxis, according to Paul, must therefore be prepared to be critical of its traditions. Christian theology must maintain the freedom not to be bound to the past in a totally inflexible way'. Wat Tuckett hier van Christelike teologie sê, kan net so van toepas- 
sing gemaak word op die verkondiging. Dit beteken dat Paulinies gesproke daar nie so iets kan wees as verkondiging wat deur die tradisie, of dan meer spesifiek, deur die belydenis vooraf bepaal kan word nie. Die kerk kan nie vandag reeds weet of vaslê wat hy môre gaan verkondig nie. Paulinies gesproke kan die belydenis alleen rigtinggewend vir die verkondiging wees vir sover dit kan meehelp om tot 'n verstaan van die evangelie, wat vir elke nuwe tyd en situasie verkondig moet word, te kom. Die verkondiging is van so ' $n$ aard dat dit in elke nuwe situasie nuut is en nuut moet wees. Dit kan dus nie deur formules gebind word nie, al kan dit soos in die geval van Paulus voluit gebruik maak van die verskillende fasette van die evangelie wat daar in die belydenis(se) verwoord is. Dit is egter nie die belydenis wat verkondig word nie maar die evangelie, en die evangelie kan nie gebind word nie. Ek kan kwalik aan 'n beter afsluiting vir hierdie studie dink as die volgende woorde van. Wegenast (1962:168):

\begin{abstract}
Sachgemäße Verkündigung scheint mir aus ebendiesen Erwägungen heraus nicht in einer Rezitation der neutestamentlichen 'Texte' bestehen zu können - auch nicht in einer Rezitation der lutherischen oder sonst einer Interpretation - , die ja gar nicht mehr Verkündigung in verständlicher Rede wäre, sondern nur in einer durch das ursprüngliche Zeugnis auf Grund der Auslegung erzeugten Verkündigung, in der sich wirklich eine Weitergabe des zu Verkündigenden, 'der Tradition', die der Christus ist, vollzieht.
\end{abstract}

\title{
Literatuurverwysings
}

Barth, G 1979. Der Brief an die Philipper. Zürich: Theologischer Verlag. (ZBK.NT 9.)

Bauer, W [1934] 1971. Orthodoxy and heresy in earliest Christianity, tr by a team from the Philadelphia Seminar on Christian Origins. London: SCM. (NTLi.)

Beare, F W 1969. The epistle to the Philippians. 2nd ed. London: Adam \& Charles Black. (BNTC.)

Bornkamm, G 1970. Zum Verständnis des Christus-Hymnus Phil 2, 6-11, in Studien zu Antike und Urchristentum, 177-187. München: Kaiser. (BEvTh 28.)

Bultmann, R 1968. Theologie des Neuen Testaments. 6. Aufl. Tübingen: Mohr.

Conzelmann, H 1968. Grundriss der Theologie des Neuen Testaments. 2. Aufl. München: Kaiser.

Deichgräber, R 1967. Gotteshymnus und Christushymnus in der frihen Christenheit: Untersuchungen zu Form, Sprache und Stil der frühchristlichen Hymnen. Göttingen: Vandenhoeck. (StUNT 5.) 
Dunn, J D G 1977. Unity and diversity in the New Testament: An inquiry into the character of earliest Christianity. London: SCM.

- 1988. Romans 1-8. Dallas: Word Books. (Word Biblical Commentary 38a.)

Gnilka, J 1968. Der Philipperbrief. Freiburg: Herder. (HThK 10.)

Hahn, F 1969. The titles of Jesus in Christology: Their history in early Christianity, tr by Harold Knight and George Ogg. London: Lutterworth Press. (LuttL.)

Hawthome, G F 1983. Philippians. Waco: Word Books. (Word Biblical Commentary 43.)

Hofius, O 1976. Der Christushymnus Philipper 2,6-11: Untersuchungen zu Gestalt und Aussage eines urchristlichen Psalms. Tübingen: Mohr. (WUNT 17.)

Jeremias, J 1963. Zu Phil ii 7: 'EATTON 'EKENREEN. NT 6, 182-188.

Käsemann, E [1950] 1960a. Zum Verständnis von Römer 3,24-26, in Exegetische Versuche und Besinnungen Erster Band, 96-100. Göttingen: Vandenhoeck.

Käsemann, E [1950] 1960b. Kritische Analyse von Phil. 2,5-11, in Exegetische Versuche und Besinnungen Erster Band, 51-95. Göttingen: Vandenhoeck.

1974. An die Romer. 2. durchges. Aufl. Tübingen: Mohr. (HNT 8a.)

Kraftchick, S J 1993. A necessary detour: Paul's metaphorical understanding of the Philippian hymn. HBT 15, 1-37.

Kramer W 1966. Christ, Lord, Son of God, tr by Brian Hardy. London: SCM. (SBT 50.)

Lohmeyer E [1928] 1961. Kyrios Jesus: Eine Untersuchung zu Phil. 2,5-11. 2. Aufl. Heidelberg: Carl Winter Universitätsverlag. (SHAkW.PH 4.)

Longenecker, B W 1993. Miorıs in Romans 3.25: Neglected evidence for the 'faithfulness of Christ'? NTS 39, 478-480.

Martin R P [1967] 1983. Carmen Christi: Philippians ii.5-11 in recent interpretation and in the setting of early Christian worship. Rev. ed. Grand Rapids: Eerdmans.

Mengel, B 1982. Studien zum Philipperbrief: Untersuchungen zum situativen Kontext unter besonderer Berücksichtigung der Frage nach der Ganzheitlichkeit oder Einheitlichkeit eines paulinischen Briefes. Tübingen: Mohr. (WUNT 2.Reihe 8.)

Müller, U B 1988. Der Christushymnus Phil 2:6-11. ZNW 79, 17-44.

1993. Der Brief des Paulus an die Philipper. Leipzig: Evangelische Verlagsanstallt. (ThHK 11/I.)

Nagata, T 1981. Philippians 2:5-11: A case study in the contextual shaping of early Christology. Ann Arbor: University Microfilms International.

Schlier, H 1972. Zu Rom 1, 3f, in Baltensweiler, H \& Reicke, Bo (Hrsg), Neues Testament und Geschichte: Historisches Geschehen und Deutung im Neuen Testament. Oscar Cullmann zum 70. Geburtstag, 207-218. Tübingen: Mohr. 1979. Der Römerbrief. 2. Aufl. Freiburg: Herder. (HThK.) 
Schmithals, W 1994. Theologiegeschichte des Urchristentums: Eine problemgeschichtliche Darstellung. Stuttgart: Kohlhammer.

Silva, M 1992. Philippians. Grand Rapids: Baker Book House. (Baker Exegetical Commentary on the New Testament.)

Tuckett, C M 1991. Paul, tradition and freedom. ThZ 47, 307-325.

Wegenast, K 1962. Das Verstandnis der Tradition bei Paulus und in den Deuteropaulinen. Neukirchen: Neukirchener Verlag. (WMANT 8.)

Wengst, K 1967. Christologische Formeln und Lieder des Urchristentums. Bonn: Rheinische Friedrich-Wilhelm-Universität.

Wilckens, U 1978. Der Brief un die Römer. 1.Teilband: Röm 1-5. Köln: Benziger. (EKK VI/1.) 